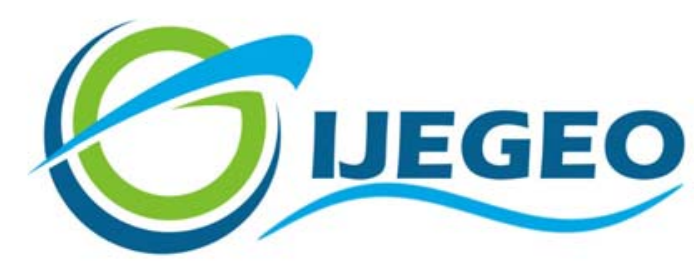

International Journal of Environment and Geoinformatics (IJEGEO) is an international, multidisciplinary, peer reviewed, open access journal.

\title{
The Bacteriological Risk Transported to Seas by Rivers; the Example of Çırpıcı River, Istanbul, TR
}

\section{Onnocan HULYAR, Gülșen ALTUĞ}

\author{
Chief in Editor \\ Prof. Dr. Cem Gazioğlu \\ Co-Editors \\ Prof. Dr. Dursun Zafer Şeker, Prof. Dr. Şinasi Kaya, \\ Prof. Dr. Ayşegül Tanık and Assist. Prof. Dr. Volkan Demir
}

Editorial Committee (April 2020)

Assos. Prof. Dr. Abdullah Aksu (TR), Assit. Prof. Dr. Uğur Algancı (TR), Prof. Dr. Bedri Alpar (TR), Prof. Dr. Lale Balas (TR), Prof. Dr. Levent Bat (TR), Prof. Dr. Paul Bates (UK), İrşad Bayırhan (TR), Prof. Dr. Bülent Bayram (TR), Prof. Dr. Luis M. Botana (ES), Prof. Dr. Nuray Çağlar (TR), Prof. Dr. Sukanta Dash (IN), Dr. Soofia T. Elias (UK), Prof. Dr. A. Evren Erginal (TR), Assoc. Prof. Dr. Cüneyt Erenoğlu (TR), Dr. Dieter Fritsch (DE), Assos. Prof. Dr. Çiğdem Göksel (TR), Prof.Dr. Lena Halounova (CZ), Prof. Dr. Manik Kalubarme (IN), Dr. Hakan Kaya (TR), Assist. Prof. Dr. Serkan Kükrer (TR), Assoc. Prof. Dr. Maged Marghany (MY), Prof. Dr. Michael Meadows (ZA), Prof. Dr. Nebiye Musaoğlu (TR), Prof. Dr. Erhan Mutlu (TR), Prof. Dr. Masafumi Nakagawa (JP), Prof. Dr. Hasan Özdemir (TR), Prof. Dr. Chryssy Potsiou (GR), Prof. Dr. Erol Sarı (TR), Prof. Dr. Maria Paradiso (IT), Prof. Dr. Petros Patias (GR), Prof. Dr. Elif Sertel (TR), Prof. Dr. Nüket Sivri (TR), Prof. Dr. Füsun Balık Şanlı (TR), Prof. Dr. Uğur Şanlı (TR), Duygu Ülker (TR), Assoc. Prof. Dr. Oral Yağc1 (TR), Prof. Dr. Seyfettin Taş (TR), Assoc. Prof. Dr. Ömer Suat Taşkın (US), Dr. İnese Varna (LV), Dr. Petra Visser (NL), Prof. Dr. Selma Ünlü (TR), Assoc. Prof. Dr. İ. Noyan Yilmaz (AU), Prof. Dr. Murat Yakar (TR), Assit. Prof. Dr. Sibel Zeki (TR)

Abstracting and Indexing: TR DIZIN, DOAJ, Index Copernicus, OAJI, Scientific Indexing Services, International Scientific Indexing, Journal Factor, Google Scholar, Ulrich's Periodicals Directory, WorldCat, DRJI, ResearchBib, SOBIAD 
Reaserch Article

\title{
The Bacteriological Risk Transported to Seas by Rivers; the Example of Çırpıcı River, Istanbul, TR
}

\author{
Onnocan Hulyar, iD Gülşen Altuğ* iD \\ Istanbul University, Faculty of Aquatic Sciences, Department of Marine Biology, Fatih 34116 TR \\ * Corresponding author: G. Altuğ \\ E-mail: galtug@istanbul.edu.tr
}

Received 16 March 2020

Accepted 25 March 2020

How to cite: Hulyar \& Altuğ (2020). The Bacteriological Risk Transported to Seas by Rivers; the Example of Çırpıcı River, Istanbul, Turkey, International Journal of Environment and Geoinformatics (IJEGEO), 7(1): 45-53. DOI: 10.30897/ijegeo.704260

\begin{abstract}
The identification of bacteriologically characters of coastal areas is important due to the fact that bacteriological pollution, transported to seas via rivers is a potential threat for ecosystem, animal and human health. In this study, bacteriological load of Çırpıc1 River transporting to Sea of Marmara from Zeytinburnu location in Istanbul and its relationship with variable environmental parameters investigated. The levels of fecal coliform (FC), total coliform (TC), fecal streptococci (FS) and total heterotrophic aerobic bacteria (HAB) tested using Membrane Filtration Technique in the surface water samples. Seawater temperature, $\mathrm{pH}$, salinity, dissolved oxygen were recorded in-situ using multiparameter (YSI556 MPS). While the highest TC detected to be $13 \times 10^{7}$ CFU/100 $\mathrm{ml}$, the highest FC was $14 \times 10^{6} \mathrm{CFU} / 100 \mathrm{ml}$. The lowest FC recorded as $223 \mathrm{CFU} / 100 \mathrm{ml}$. While the highest FS level was determined to be $73 \times 10^{5} \mathrm{CFU} / 100 \mathrm{ml}$, the highest $\mathrm{HAB}$ was $14 \times 10^{6} \mathrm{CFU} / \mathrm{ml}$. Variable environmental parameters recorded for seawater temperature between $10.3-29.5^{\circ} \mathrm{C} ; \mathrm{pH} 6.0-8.38$; dissolved oxygen $0.34-10.71 \mathrm{mg} / \mathrm{l}$ and salinity $16.50-26.57 \mathrm{psu}$ during the study period. Significant correlation between the temperature and FC, FS and HAB detected. The levels of bacteria detected at the spot where the Cirpic1 River poured into Sea of Marmara were found higher than the station at the $800 \mathrm{~m}$ open of Sea of Marmara. It was determined that the Çırpıcı River carried $10^{3} \mathrm{CFU}$ bacterial loads at $100 \mathrm{ml}$ for TC to Sea of Marmara. The FC and FS counts carried to Marmara Sea from Çrpıcı River recorded to be $10^{2} / 100 \mathrm{ml}$ and $10^{3} / 100 \mathrm{ml}$, respectively. The fact that FC and TC levels were above the limit values during the study indicate the stability of pollution sources in the region and that the Çırpıc1 Stream carries a bacteriological risk in terms of human, animal, and environmental health.
\end{abstract}

Keywords: Fecal Coliform, Total Coliform, Heterotrophic Bacteria, Sea of Marmara, Çırpıcı River

\section{Introduction}

The Intergovernmental Oceanographic Commission of UNESCO (IOC-UNESCO) describes the water contamination as "the introduction of substances that are adverse to the live resources that are harmful for human health, that are deterrent in terms of the activities in seas including the fishery and that may have damaging impact on the aquatic biomass by humans in a direct or indirect manner". The transfer of pollution as the result of the waste water discharges and the river overflows that occur due to excessive rainfall may result in adverse effects in marine environments. Most of the bacteria in the residential waste water are comprised of fecal or ground based saprophytic bacteria. Furthermore, pathogenic bacteria such as the Salmonella, Brucella, Mycobacterium, Leptospira, Campylobacter and Vibrio may mix into the seas through residential waste. Apart from these, Adenovirus, Reovirus, Rotavirus and hepatitis viruses as well as the protozoan such as Entamoeba histolytica, Giardia lamblia, Cryptosporidium may also be introduced to the seas via the sewage water (WHO, 2004). Searching pathogenic bacteria one by one in sea water is a method that requires analytic expertise and takes too much time in addition to the fact that this method is far from being far from financially reasonable. That is why, the use of total coliforms, fecal coliforms and fecal streptococci, which share the same environment with the pathogenic bacteria, which are numerically superior to the pathogenic bacteria and which takes less time to determine in a more economical manner, is much common in routine analyses as the indicator of the presence of the pathogenic bacteria (Droste, 1997; APHA 1998, Prescot et al, 1999, Bitton, 2005).

The levels of the bacteria, found in the sea water, may vary based on the physiochemical and biological factors such as the water temperature, the phenomena of absorption and sedimentation, the toxic impact of the heavy metals, sunlight, degradation by the bacteria, viruses and protozoon, the lack of nutrients, local flora and competition (Borrego et al., 1983). Since the enteric bacteria experience sudden osmotic shock right after being introduced to sea water, they can adapt their metabolism to their new environment via their osmosisregulatory systems. This ability of the enteric bacteria increases their odds to survive in by developing resistance to salt in marine environments (Munro et al., 1989). The sea water temperature has various effects in different species. Rhodes and Kator (1988), reported that the E.coli proceeds to its death phase faster in temperatures below $10^{\circ} \mathrm{C}$ compared to Salmonella species. On the other hand, there are studies, indicating 
that the rise in water temperatures is in direct proportion with the increase in the number of enteric bacteria (Sorensen, 1991; APHA, 1998; Bitton, 2005). It was found out that there is a negative correlation between the salt concentrations and the number of the enteric bacteria in marine environment (Carlucci et al., 1960; APHA, 1998; Bitton, 2005).

The main goal in regards to discharging waste water to seas is diluting the waste water by mixing them with sea water thus bringing the level of the pollutant within the waste water down to non-harmful degrees. Bringing down the bacteria concentrations to lower levels are important in terms of public health and the eco-system. The United Nations Sea Pollution Research Group indicated that the residential waste originated pollution has the primary significance level while the heavy metal and petroleum pollution has a secondary degree of importance. This find is due to the fact that the threat that the residential waste water poses for the public health is larger than its damage, inflicted upon the marine environments (EPA, 1998).

The poor urbanization, rapid population increase and the ever growing industrial activities in Istanbul, which is the most populated city in Turkey, have resulted in serious environmental pollution, especially in terms of marine environments. Sea of Marmara plays a significant role in Turkish fishing industry. Sea of Marmara, which hosts an urban center like Istanbul, also constitutes one of the most important water roads in the world and is under the pressure of chemical and biological pollution, resulting from the residential industrial pollution in addition to the pollution due to marine transportation. There are studies, reporting that the rivers carry pollution to Sea of Marmara (Hacioğlu and Dülger, 2009; Gürün and Erdem, 2013; Altuğ et al., 2016 b).

The Çırpıcı River, which flows into Sea of Marmara, is amongst the waters with the highest risk according to the environmental assessments. This river passes through the districts of Bakırköy, Bağcılar, Güngören, Esenler and Bayrampaşa. The length of the river is $21,5 \mathrm{~km}$ 's. It is exposed to the risk of pollution depending on the industrial sites that surround it.

The rivers that are described as the focal points of the terrestrial based bacteriological pollution play a significant role in the pollution of Sea of Marmara. There is no detailed temporal and spatial data that presents the heterotrophic aerobic bacteria and indicator bacteria transported to Sea of Marmara via the Cirpıc1 River, at the shores of Zeytinburnu in European side, in a manner with current data. In this study, the month and season based distribution of the bacteriological load that the Crrpicı River, which is considered as one of the possible pollution sources for Sea of Marmara was investigated associated with variable environmental parameters such as temperature, salinity, dissolved oxygen and $\mathrm{pH}$.

\section{Material and Methods}

Study area and sampling

The sampling of the surface waters $(0-30 \mathrm{~cm})$ was made from the stations selected as the point, where the Çırpıcı River, flows into Sea of Marmara at the shores of Zeytinburnu (in front of the Zeytinburnu Fishing Port) and as the subsequent ones selected to be 800 meters apart from this point towards the direction of the current, against the current and at the discharge point. The sampling plan of the study was shown on Table 1 . Location of the sampling stations were shown in Figure 1 and Table 2.

Table 1.The Sampling Plan of the Study

\begin{tabular}{|l|l|l|}
\hline Season & Sampling Type & Sampling Date \\
\hline Spring & Seasonally & May 2014, \\
& & April 2015 \\
\hline Summer & Montly & June 2014 \\
& & July 2014 \\
& & June 2015 \\
& & July 2015 \\
\hline Autumn & Seasonally & August 2015 \\
\hline Winter & Seasonally & December 2014 \\
\hline
\end{tabular}

Sampling were performed in 2014-2015 as monthly between May and August, when the bacteriologic activity is high and as seasonal in winter and spring seasons. The sea water samples were collected from the surface from the depth of $0-30 \mathrm{~cm}$ under aseptic conditions with sterile glass tubes and were analyzed within 4-6 hours after being transferred to the laboratory under the cold chain (APHA, 1998; EPA, 2006).

The variable environmental parameters (temperature, salinity, dissolved oxygen, $\mathrm{pH}$ ) were measured in-situ by using a multi-parameter probe. (YSI Model 556).

\section{Bacteriological Analyses}

The membrane filtration system was used for the fecal streptococcus, fecal coliform and the total coliform analyses. As for the medium, m.FC-NKS (Sartorius) was used for fecal coliform, Endo-NKS (Sartorius) was used for the total coliform while Azide-NKS (Sartorius) nutrient pad system was used for fecal streptococcus.

The samples incubated at $44.5 \pm 0.1{ }^{\circ} \mathrm{C}$ for 24 hours for fecal coliform and at $37 \pm 0.1{ }^{\circ} \mathrm{C}$ for $24 \mathrm{hrs}$ for fecal streptococcus. In the post incubation phase, the blue colonies, grew at mFC NKS were considered as the fecal 
coliform suspects while the dark red - metallic green colonies, grew in Endo-NKS are marked for total coliform suspects and the brown-red colonies, grew in Azide-NKS were marked as fecal streptococcus suspects and the indicator bacteria count for the suspected colonies of $100 \mathrm{ml}$ was calculated by implementing the following formula; [CFU (Colony Formed Unit) /100 ml $=($ Number of colony $\mathrm{x} 100) /$ filtered volume $(\mathrm{ml})]$ (APHA, 2006).

The suspected blue colonies of fecal coliform, grew in $\mathrm{mFC}$ medium that were determined to be Gram negative asporogenic rod bacteria were subjected to cytochrome oxidize test and the ones that came up with negative results were marked as fecal coliform. The total cultivable heterotrophic aerobic bacteria count was determined by using the marine dispersion agar method (Austin, 1988).

\section{Statistical Analyses}

The SPSS 19.0 (Statistical Package for the Social Science) software package and the Kolmogrov-Smirnov (K-S) test, $\mathrm{x}$-square independence sample test, onewayANOVA test or its non-parametric alternative, the Mann Whitney $U$ test and the variance analysis test were separately applied to the extracted data. Throughout the study, the significance levels were marked as 0,01 and 0,05 . In order to determine the impact of the season and station factors on the changes in the pre-determined environmental parameters, oneway variance analysis was employed and to find out the interrelations of the parameters with each other, Spearman linear correlation analysis was used. MannWhitney $U$ test was used in a dual setting to determine the differences between the stations. (Quinn ve Keough, 2002).

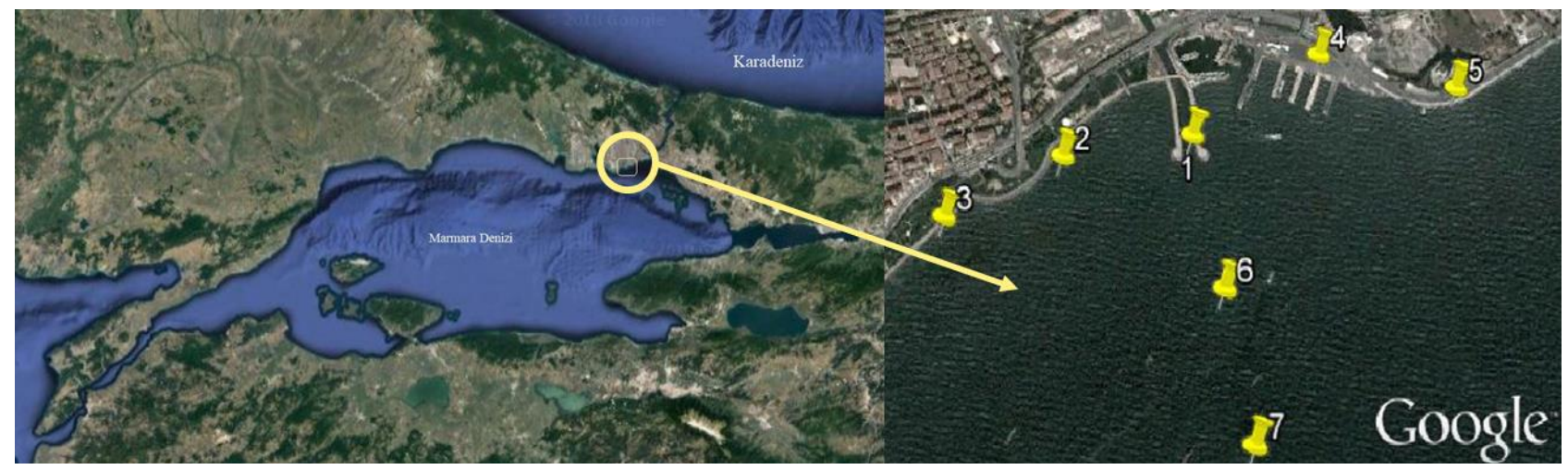

Fig. 1 Sampling Stations (Google Maps)

Table 2 Location of the Sampling Stations

\begin{tabular}{clcc}
\hline Station Number & Station Location & Latitude & Longitude \\
\hline 1 & Çirpici River -Exit & $40^{\circ} 58^{\prime} 48.0^{\prime \prime} K$ & $28^{\circ} 53^{\prime} 27.8^{\prime \prime} D$ \\
2 & Exit 400 m & $40^{\circ} 58^{\prime} 41.6^{\prime \prime} K$ & $28^{\circ} 53^{\prime} 12.3^{\prime \prime} D$ \\
3 & Sea of Marmara-Right $800 \mathrm{~m}$ & $40^{\circ} 58^{\prime} 35.5^{\prime \prime} \mathrm{K}$ & $28^{\circ} 52^{\prime} 58.3^{\prime \prime} D$ \\
4 & Sea of Marmara-left 400m & $40^{\circ} 58^{\prime} 44.1^{\prime \prime} \mathrm{K}$ & $28^{\circ} 53^{\prime} 44 .^{\prime \prime} D$ \\
5 & Sea of Marmara-left 800m & $40^{\circ} 58^{\prime} 42.2^{\prime \prime} \mathrm{K}$ & $28^{\circ} 54^{\prime} 01.0^{\prime \prime} D$ \\
6 & Sea of Marmara-open 400 m & $40^{\circ} 58^{\prime} 35.3^{\prime \prime} \mathrm{K}$ & $28^{\circ} 53^{\prime} 28.0^{\prime \prime} D$ \\
7 & Sea of Marmara-open $800 \mathrm{~m}$ & $40^{\circ} 58^{\prime} 22.3^{\prime \prime} \mathrm{K}$ & $28^{\circ} 53^{\prime} 27.7^{\prime \prime} D$ \\
\hline
\end{tabular}

\section{Results}

Total coliform, fecal coliform, fecal streptococcus and total mesophilic heterotrophic aerobic bacteria (HAB) analyses were performed to the surface water samples, extracted between May 2014 and November 2015, from 7 stations in the areas, where the Çırpıcı River flows into Marmara Sea at the shores of Zeytinburnu.

For the European Parliament, the standard values are 500 cfu/100 $\mathrm{ml}(2,69 / 100 \mathrm{ml}$ according to $\log 10$ value $)$ for the total coliform count, $100 \mathrm{cfu} / 100 \mathrm{ml}(2.0 / 100 \mathrm{ml}$ according to $\log 10$ value) for fecal coliform and 100 $\mathrm{cfu} / 100 \mathrm{ml}(2.0 / 100 \mathrm{ml}$ according to $\log 10$ value $)$ for the fecal streptococcus and the aforementioned standards are underlined as dark red in the following charts (European Parliament, 2006). The levels of total coliform bacteria in the stations were shown in Figure 2. The levels of fecal coliform bacteria in the stations were shown in Figure 3. 


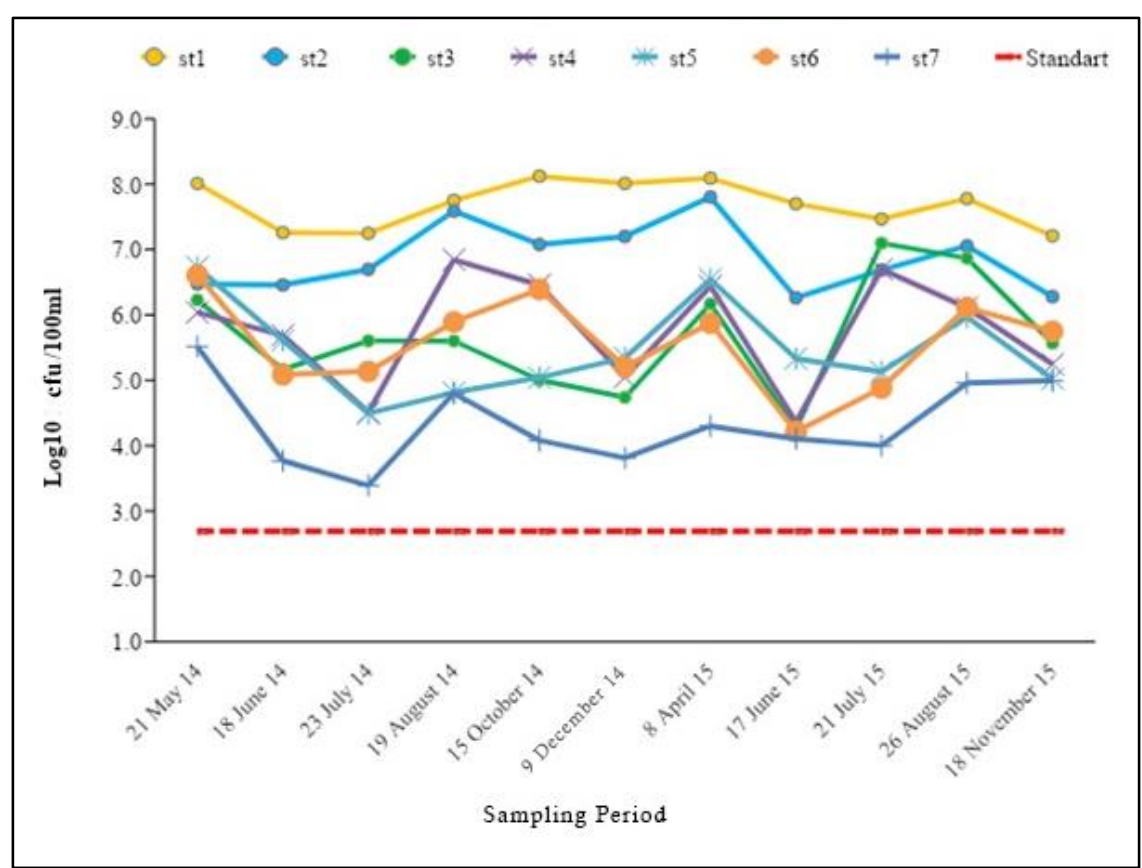

Fig. 2 Levels of total coliform bacteria in the stations.

When all stations are compared, the lowest total coliform value was measured in Station 7 in July 2014 as $25 \times 10^{2}$ $\mathrm{cfu} / 100 \mathrm{ml}$ while the highest total coliform value was found out to be $13 \times 10^{7} \mathrm{cfu} / 100$ in Station 1 in October 2014.

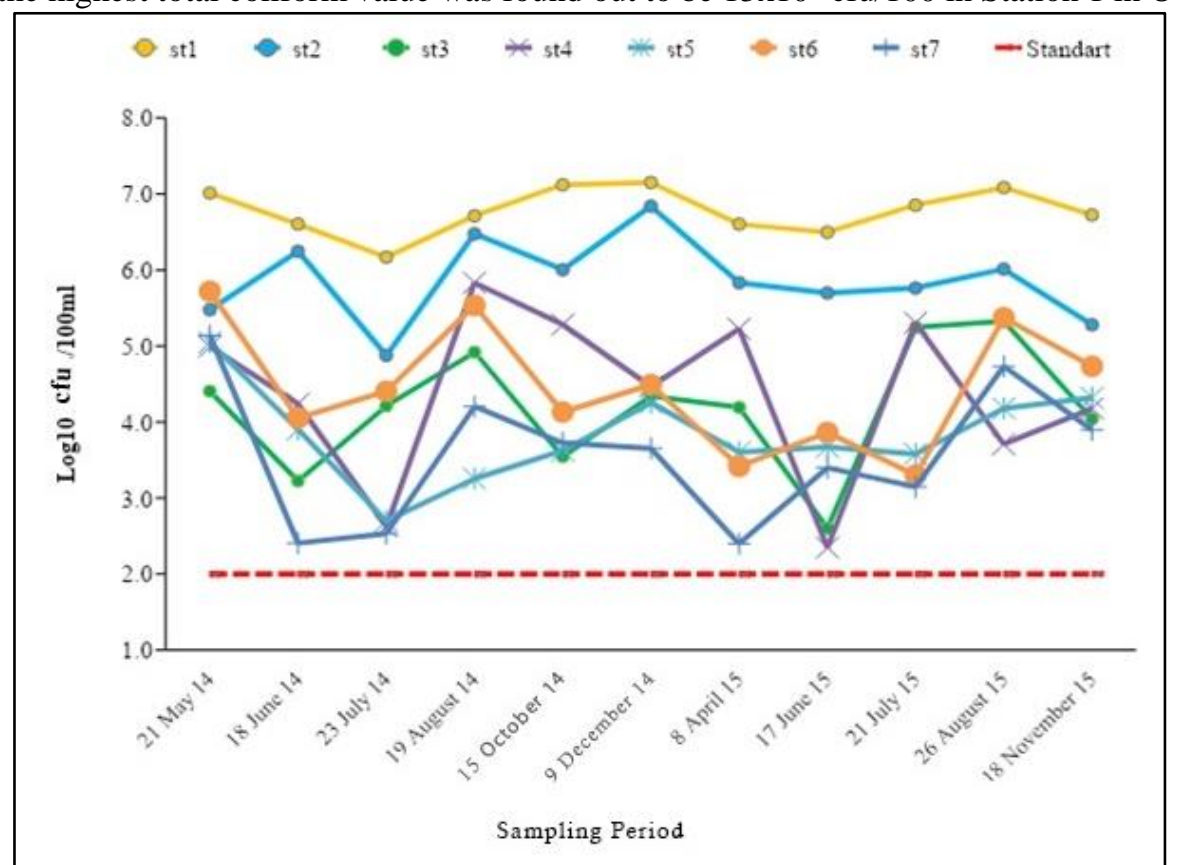

Fig. 3 Levels of fecal coliform bacteria in the stations

The lowest fecal coliform value across all stations was measured in Station 4 in June 2015 as $223 \mathrm{cfu} / 100 \mathrm{ml}$ while the apex value was 14x10 $\mathrm{cfu} / 100 \mathrm{ml}$, measured in Station 1 in December 2014.

The levels of fecal streptococci in the stations were shown in Figure 4. The levels of total mesophilic heterotrophic aerobic bacteria (HAB) in the stations were shown in Figure 5. 


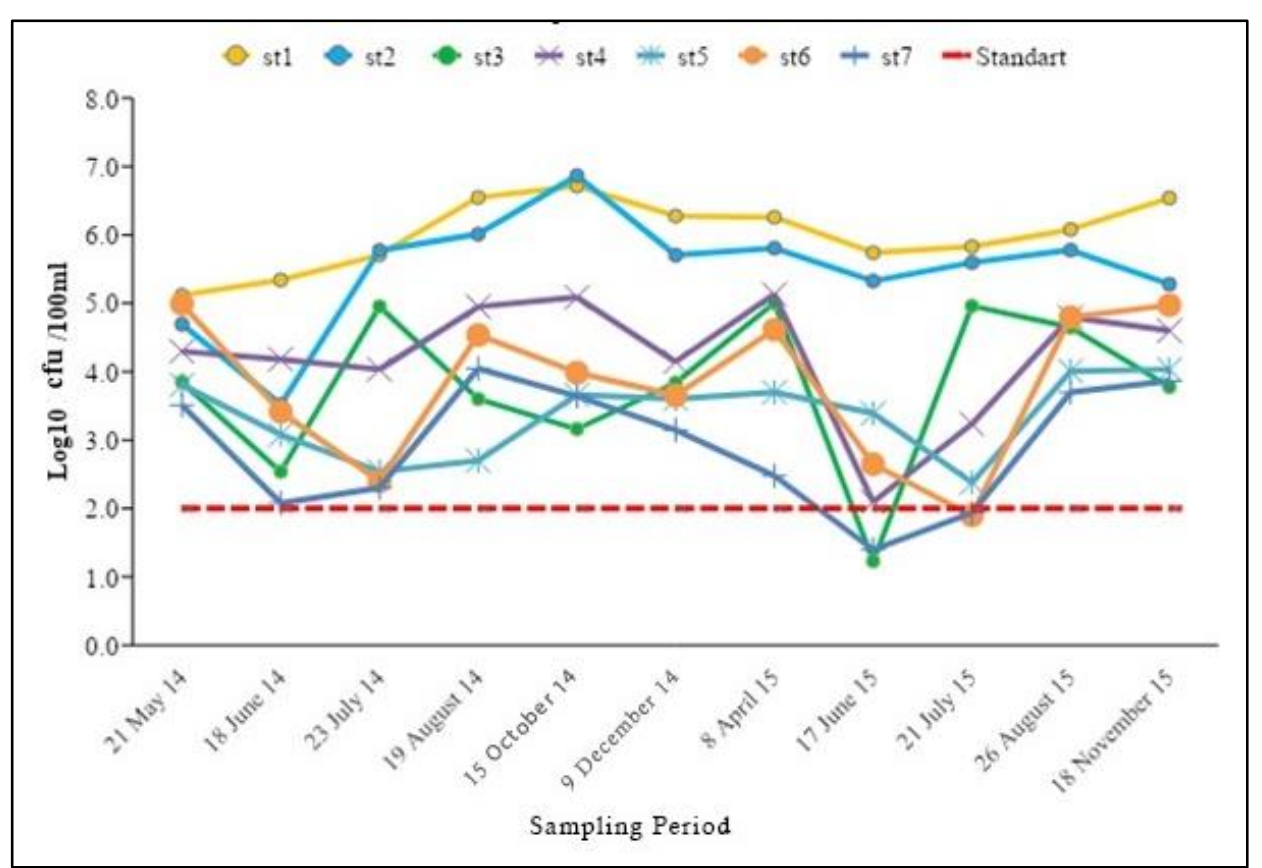

Fig. 4 The levels of fecal streptococci in the stations

As the result of the analysis of all stations, the lowest fecal streptococci value was recorded in Station 3 in June 2015 as $17 \mathrm{cfu} / 100 \mathrm{ml}$ while the highest fecal streptococci value was found in Station 2 in October 2014 as $73 \times 10^{5} \mathrm{cfu} / 100 \mathrm{ml}$.

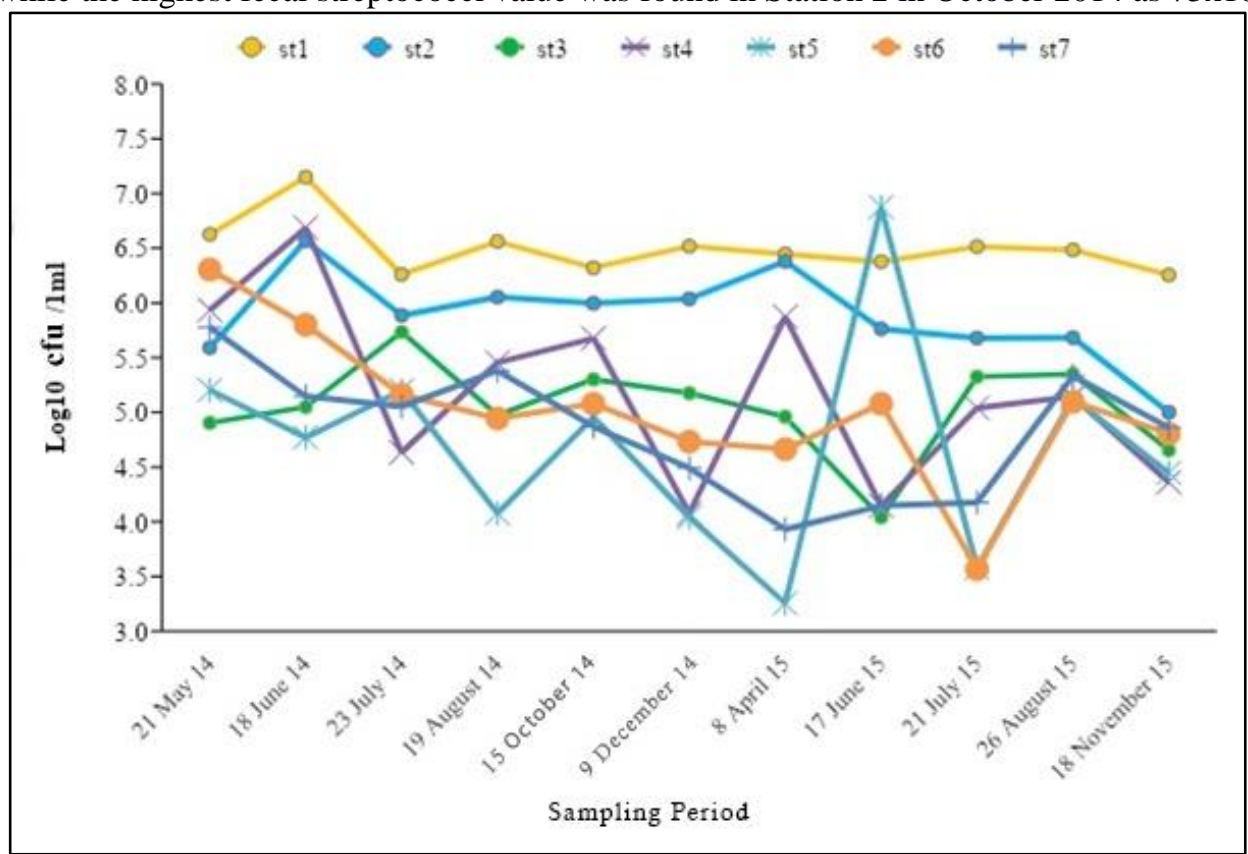

Fig. 5 The total mesophilic heterotrophic aerobic bacteria (HAB) in the stations.

When all stations were compared, the lowest HAB was recorded in Station 5 in April 2015 as $18 \times 10^{2} \mathrm{cfu} / 100 \mathrm{ml}$ and the highest $\mathrm{HAB}$ value was found out to be $14 \times 10^{6} \mathrm{cfu} / 100 \mathrm{ml}$, measured in Station 1 in June 2014.

The levels of dissolved oxygen, temperature, salinity and $\mathrm{pH}$ values were shown in Figure 6.

The correlation co-efficient for the comparison of the variable parameters with stations was shown in Figure 7. 


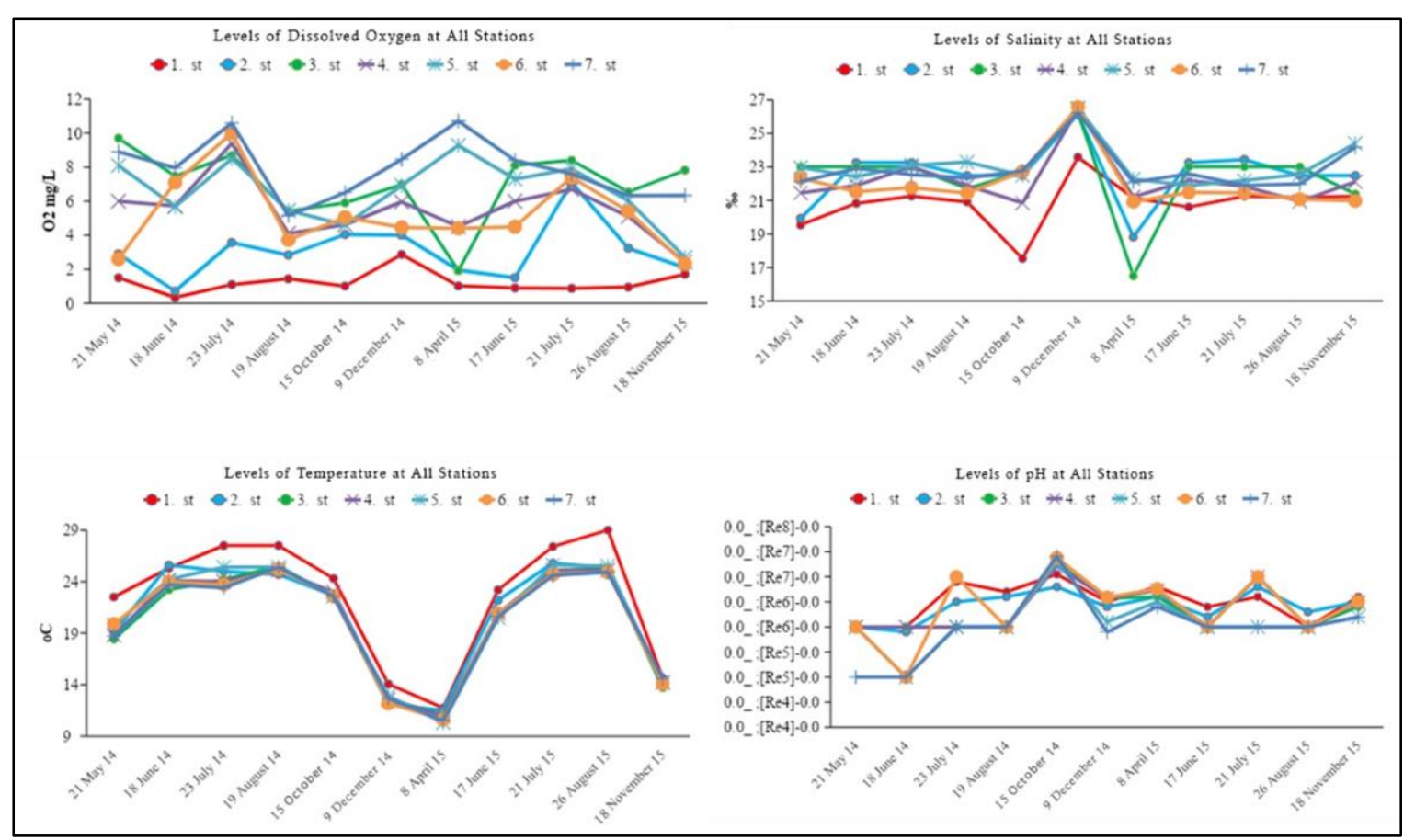

Fig. 6. The levels of dissolved oxygen, temperature, salinity and $\mathrm{pH}$ values during the study.

\begin{tabular}{|c|c|c|c|c|c|c|c|c|c|c|}
\hline \multirow{2}{*}{\multicolumn{2}{|c|}{ Spearman's rho FC }} & & \multirow{2}{*}{$\begin{array}{l}\text { FC } \\
1,000\end{array}$} & \multirow{2}{*}{ TC } & \multirow[t]{2}{*}{$\mathrm{FS}$} & \multirow[t]{2}{*}{ HPC } & \multirow[t]{2}{*}{ Temp. } & $\begin{array}{c}\text { Dissolved } \\
\text { Oxygen } \\
\end{array}$ & \multirow[t]{2}{*}{ Salinity } & \multirow[t]{2}{*}{$\mathrm{pH}$} \\
\hline \multirow{24}{*}{ Spearman's rho } & & Correlation Coefficient & & & & & & & & \\
\hline & & Sig. (2-tailed) & & & & & & & & \\
\hline & & $\mathrm{N}$ & 77 & & & & & & & \\
\hline & \multirow[t]{3}{*}{$\mathrm{TC}$} & Correlation Coefficient & & & & & & & & \\
\hline & & Sig. (2-tailed) & & & & & & & & \\
\hline & & $\mathrm{N}$ & & & & & & & & \\
\hline & \multirow[t]{3}{*}{ FS } & Correlation Coefficient & & $5^{\circ}$ & & & & & & \\
\hline & & Sig. (2-tailed) & & & & & & & & \\
\hline & & $\mathrm{N}$ & & & & & & & & \\
\hline & \multirow[t]{3}{*}{ HPC } & Correlation Coefficient & &, $685^{\prime \prime}$ & $.655^{\circ}$ & & & & & \\
\hline & & Sig. (2-tailed) & &, 000 &, 000 & & & & & \\
\hline & & $\mathrm{N}$ & & 77 & 77 & & & & & \\
\hline & \multirow[t]{3}{*}{ Temp. } & Correlation Coefficient &, 160 &, 131 &, 039 & 57 & & & & \\
\hline & & Sig. (2-tailed) & , 165 & 255 &, 737 & 024 & & & & \\
\hline & & $\mathrm{N}$ & 77 & 77 & 77 & 77 & & & & \\
\hline & \multirow{3}{*}{$\begin{array}{l}\text { Dissolved } \\
\text { Oxygen }\end{array}$} & Correlation Coefficient & &,$- 650^{* \prime}$ & &,$- 533^{\prime \prime}$ &,- 081 & & & \\
\hline & & Sig. (2-tailed) & &, 000 & &, 000 &, 482 & & & \\
\hline & & $\mathrm{N}$ & & 77 & & 77 & 77 & & & \\
\hline & \multirow[t]{3}{*}{ Salinity } & Correlation Coefficient & & $71^{2}$ & -1 & 314" &,- 085 & $404^{4}$ & & \\
\hline & & Sig. (2-tailed) & & & & 005 &, 461 & .000 & & \\
\hline & & $\mathrm{N}$ & & r & & 71 & 77 & & & \\
\hline & \multirow[t]{3}{*}{$\mathrm{pH}$} & Correlation Coefficient & & $329^{\circ}$ & $97^{\circ}$ &, 048 &,- 174 & 282 &,- 128 & 1,000 \\
\hline & & Sig. (2-tailed) & & 004 & &, 681 &, 130 & 013 & 268 & \\
\hline & & $\mathrm{N}$ & & 71 & 71 & 77 & 77 & 77 & 77 & 77 \\
\hline
\end{tabular}

Fig. 7. The correlation co-efficients for the comparison of the variable parameters with stations

When the correlation co- efficient are analysed for the comparison of the variable parameters with stations, it is indicated that a high level of relevance between the ones, underlined with red while the ones, marked with yellow point out a moderate level of relation. The ones that were indicated with pink and blue on the other hand, signify a 
weak correlation. While there are is no relationship between the fecal coliform and the total coliform values at station 1, there is a significant relationship between fecal coliform values at in Stations 3 and $6(p<0,01)$.

\section{Discussion and Conclusion}

It is apparent that the bacteriological studies, initiated in 80 's in the Sea of Marmara have been towards the indicator bacteria. From time to in such studies, the presence of the indicator bacteria in levels exceeding the standard values has been reported (Çevikol, 1982). Bayhan et al. (1998) reported seasonal fecal coliform levels in Sea of Marmara and Bosporus below the WHO standards. Altuğ et al. (2016 b) in the monitoring studies they conducted in the shoreline of Istanbul between 2000-2016, recorded the presence of indicator bacteria above the limit values although they also recorded stations with occasional declines.

In many river and stream studies, it is pointed out that the most polluted areas are the zones, where the rivers merge with the sea (Neill, 2004; Shen et al. 2006; Baums et al., 2007; Touron et al., 2007). In this study, which included the point, where the Çırpıcı River flows into the sea, pathogen bacteria species from 17 families were reported. In the dissertation, conducted on Sea of Marmara, Çiftçi (2008) reported that throughout the sampling period, they found out a higher indicator bacteria at the point, where the Çırpıcı River flows right into Marmara Sea especially at the station, located in the shore of the oil station and at the station, located at Zeytinburnu fisherman shelter compared to the other stations. Furthermore, they pointed out that the presence of both the oil station and the fisherman shelter applies more pollution pressure onto this particular station compared to the other stations and they concluded that this case is related with the pollution influx that the Çırpıcı River, which flows into Marmara Sea after charged with different pollutant influxes, carries into Sea of Marmara. In the studies regarding Marmara Sea, the terrestrial originated pollution pressure was revealed especially in the coastal areas (Çevikol, 1982; Unat et al., 1986; Kaşgar, 1992; Kimiran, 1999; Aslan-Yılmaz, 2002; Sur et al., 2005; Çiftçi, 2008; Sivri, and Seker 2010; Zeki, 2012; Altuğ et al., 2010, 2013; Çardak and Altuğ 2014; Çardak et al., 2016; Gazioğlu, 2018; Çiftçi Türetken and Altuğ, 2016, Altuğ et al., 2016a,b).

In this study, the indicator bacteria levels were researched at the point, where the Çırpıcı Rivers flows into Sea of Marmara within a period that spanned from May 2014 to November 2015 in monthly fashion during the summer months and in seasonally at other times. As the result, the bacteriological characteristics of the connection of the Çırpıcı River - Sea of Marmara was identified in terms of indicator bacteria and the heterotrophic aerobic bacteria levels. Conducting seasonal sampling for two years between May 2014 and November 2015 and examining the pollution levels that increase during the summer months in a monthly fashion as well as analyzing pollution related impact of Çırpıcı
River only at its discharge point into Sea of Marmara provided the detailed bacteriological data in the region. The obtained data was analyzed in terms of the national and international water quality standards. According to the National Regulations, published on December 31, 2004, the standard values that the sea water, used for recreational purposes should provide are as follow; 1000 $\mathrm{cfu} / 100 \mathrm{ml}(3,0 / 100 \mathrm{ml}$. acc. $\log 10)$ for total coliform, $200 \mathrm{cfu} / 100 \mathrm{ml}(2,3 / 100 \mathrm{ml}$. acc. $\log 10)$ for fecal coliform and $100 \mathrm{cfu} / 100 \mathrm{ml}(2,0 / 100 \mathrm{ml}$. acc. $\log 10)$ for fecal streptococcus. (Official Gazette, 2004) Furthermore, the standard values for the European Union are $500 \mathrm{cfu} / 100 \mathrm{ml}(2,69 / 100 \mathrm{ml}$. acc. $\log 10)$ for total coliform, $100 \mathrm{cfu} / 100 \mathrm{ml}(2,0 / 100 \mathrm{ml}$. acc. $\log 10)$ for

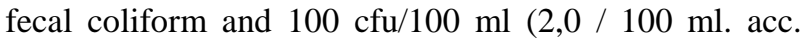
$\log 10$ ) for fecal streptococci (European Parlament, 2006).

The discharge area of Çırpıcı River into Sea of Marmara fisherman shelter, picnic fields, oil station, hotels, sports $\&$ activity areas and while not officially considered as a beach, it is still considered as a recreational area due to the fact that the area is occasionally used for swimming purposes. Another point that picked interest at the sampling point is that there are various non-legal discharge points in the vicinity right next to the discharge point and along the river. The point, where Çırpıcı River, which is a receiver for various industrial facilities and which takes a heavy amounts of residential waste from Zeytinburnu county flows into Marmara Sea (Station 1) arrives to the discharge point with a major load of pollution. In this study, the results, when compared to the other stations, indicate that the point, where Çırpıcı River flows into Sea of Marmara contains the highest amount of bacteria and all samples contain bacteria levels that exceed the legal standards. This is an indication that the environment contains pathogenic bacteria. When the samples, taken from the point, where Çırpıcı River flows into Sea of Marmara (Station 1) were compared to the station that is 800 off the shore, it was revealed that the Çırpıcı River carried 10.000 bacteria (cfu) in $100 \mathrm{ml}$. for the total coliform and fecal streptococci and 1000 bacteria for the fecal coliform. Despite the fact that the FC, TC, FS and TAHB values did not show a significant difference across the stations in the statistical analyses, the dual implemented MannWhitney $U$ Test revealed that the total values for the fecal coliform, total coliform and the total heterotrophic aerobic bacteria at the point, where Çırpıcı River flows into Sea of Marmara, are higher compared to the other stations. While a statistically significant $(\mathrm{p}<0.001)$ relation was detected between the temperature value and the total level of heterotrophic aerobic bacteria, a statistically significant negative relation $(p>0.01)$ was revealed between the dissolved oxygen, which is one of the other variable environmental parameters, and the fecal coliform and the fecal streptococci. This indicates that the temperate has an effect on the heterotrophic activity. At the same time, it was shown that the level of dissolved oxygen decreased during the periods, when the temperature rose while the levels of fecal coliform and fecal streptococci increased. 
It is a well-known fact that all over the world, the waste water is discharged into the seas in order to achieve dilution to decrease its pollutant capacity. However, depending on the discharge procedures, the relevant environment may be protected or damaged. The point based pollutant sources disrupt the ecological balance of the environment due to constant waste input and therefore change the computation conditions between the microorganisms. Therefore, the natural changes that are expected from the environmental factors at the points, where pollutant sources are present, are not experienced. With this study, as the result of the indicator bacteria analyses, conducted in a monthly manner in summer months and in seasonal manner in the other periods between May 2014 and November 2015, the bacteriological characteristics of the connection between the Çırpıcı River and Sea of Marmara was defined for the first time in terms of indicator bacteria and the heterotrophic aerobic bacteria levels. The presence of indicator bacteria, detected throughout the sampling period, shows the permanence of the pollutant sources and indicates that the Çırpıcı River carries bacteriological risk to Sea of Marmara. The study area is also open to marine transportation related indicator bacteria sources. The fact that the level of indicator bacteria that Çırpıcı River carries is defined via the data of this study also constitutes data for the information regarding general pollution, transported via creeks and rivers. In order to ensure the continuous use of the coastal areas in a healthy manner, the bacteria levels should be lowered down below the national and international standards and sustainability should be achieved in this regard.

\section{Acknowledgements}

The authors thank to İstanbul University Scientific Researches Project Unit (İ.Ü. BAP Project/43201) for their financial support. The authors also thank Dr. Pelin S. Çiftçi Türetken and $\mathrm{PhD}$ student Meryem Öztaş for their assistances in laboratory studies.

\section{References}

Altuğ G., Gürün S., Çiftçi Türetken P.S., Hulyar O., 2010, Marmara Denizi, İstanbul İli Kıyısal Alanında Patojen Bakteriler ve Bakteriyolojik Kirlilik, Marmara Denizi 2010 Sempozyumu, İstanbul, Türkiye, 25-26 Eylül 2010, no.32, ss.422-429.

Altuğ G., Gürün S., Kalkan S., Çiftçi Türetken P.S., (2016b), Marmara Denizi'nde Bakteriyolojik Kirlilik ve Yansimaları, II. Marmara Denizi Sempozyumu, İstanbul, Türkıye, 22-23 Aralık, ss.62-67.

Altuğ, G., Çardak, M., Çiftçi, P.S., Gürün, S. (2013). First Records and Microgeographical Variations of Culturable Heterotrophic Bacteria in an Inner Sea (the Sea of Marmara) Between the Mediterranean and the Black Sea, Turkey. Turkish Journal of Biology, (37), 184-190.

Altuğ, G., Çiftçi Türetken, P.S., Gürün, S., Kalkan, S. (2016a) Diversity of Bacteria Isolated Turkish Marine Areas. Workshop on Biotechnological Use of
Bacteria Proceeding Book Edit. G. Altuğ, S. 41-50. 20, İstanbul.

APHA. (1998). Standard Methods for the Examination of Water and Wastewater $20^{\text {th }}$ Edition, Clesceri, In L. S., A.E Greenberg and A.D Eaton (eds). American Public Health Association, American Water Works Association and Water Environment Federation, Washington, D.C

Aslan-Yılmaz, A. (2002). Monitoring discharges at Bosphorus, Black Sea exit of the Strait and the Northeastern Marmara Sea by indicator microorganisms, Master's Thesis. Istanbul University Institute of Marine Sciences and Management (in Turkish).

Austin, B. (1988). Marine Microbiology. Cambridge University Press, Cambridge

Baums, I.B., Goodwin, K.D., Kiesling, T., Wanless, D., Diaz, M.R., Fell, J.W., 2007, Luminex detection of fecal indicators in river samples, marine recreational water, and beach sand, Marine Pollution Bulletin, 54, 521-536.

Bayhan, H., Övez, S., Aydın, A.F., Okuş, E. (1998). Monitoring of Domestic Wastewater by Fecal Coliform Determination at Marmara, Istanbul Strait and Black Sea Exit, Wastewater Management and Marine Pollution Control Symposium in Large Cities, 123-130 (in Turkish).

Bitton, G. (2005). Wastewater Microbiology, 3th In John Wiley \& Sons, Hoboken (eds), New Jersey, I0-47165071-4.

Borrego, J.J., Arrabal, F., de Vicente ,A., Gomez, L.F., Romero, P. (1983). Study of microbial inactivation in the marine environment. Journal (Water Pollution Control Federation), (55), 297-302.

Çardak, M., Altuğ, G. (2014). Species Distribution and Heavy Metal Resistance of Enterobacteriaceae Members Isolated From Istanbul Strait, Fresenius Environmental Bulletin, 23, 2620-2626.

Çardak, M., Altuğ, G., May, M., Erol, Ö. (2016). Investigation of the Distribution of Antibiotic Resistance and the Presence of VancomycinResistance Genes (vanA and vanB) in Enterobacteriaceae Isolated from the Sea of Marmara, Canakkale Strait and Istanbul Strait, Turkey, Oceanological and Hydrobiological Studies, $1,1-5$.

Carlucci, A.F., Scarpino, P.V., Pramer, D. (1960). Evaluation of factors affecting survival of Escherichia coli in sea water studies with heat- and filter-sterilized sea water, Journal of Applied Microbiology, 9(5), 400-404.

Çevikol, E. (1982). İstanbul'u çeviren deniz sularında yaz mevsimi başında ve sonunda yapılan bakteriyolojik incelemeler, İstanbul Üniversitesi Cerrahpaşa Tıp Fakültesi, Uzmanlık tezi

Çiftçi Türetken, P.S., Altuğ, G. (2016). Bacterial pollution, activity and heterotrophic diversity of the northern part of the Aegean Sea, Turkey. Environmental Monitoring and Assessment, 188(2):127. doi: 10.1007/s10661-016-5109-6

Çiftçi, P.S. (2008). A study on the degradation ability of the bacteria isolated from the Sea of Marmara in polycyclic aromatic hydrocarbons (PAH), Istanbul 
University Institute of Graduate Studies In Sciences. Master's Thesis. (in Turkish).

Droste, R.L. (1997). Theory and practice of water and wastewater treatment, Willey and Sons, New York, 0471153573, 978-0471153573.

EPA. (1998). Improved enumeration methods for the recreational water quality indicators: Enterococci and Escherichia coli.

EPA. (2006). EPA, Microbiological alternate test procedure (ATP) protocol for drinking water, ambient water, and wastewater monitoring methods.

European Parlament. (2006). Directive 2006/7/EC of the European parlament and of the council of 15 February 2006.

Gazioğlu, C. (2018). Biodiversity, Coastal Protection, Promotion and Applicability Investigation of the Ocean Health Index for Turkish Seas. International Journal of Environment and Geoinformatics (IJEGEO), 5(3), 353-367.

Gürün, S., Kimiran Erdem, A. (2013). Examination of the Level of Bacteriological Pollution in the Discharge Area of the Ayamama Stream to the Marmara Sea. Ekoloji, 22, 48-57.

Hacıoğlu, N., Dulger, B. (2009). Monthly variation of some physico-chemical and microbiological parameters in Biga stream (Biga,Canakkale, Turkey), African Journal of Biotechnology, 8(9), 1929-1937.

Karabulut, E. (1999). Research on the distribution of microbiological pollution load in the costs of İstanbul metropolitan city, Master's Thesis, Istanbul University Institute of Marine Sciences and Management (in Turkish).

Kaşgar, S. (1992). İstanbul Boğazı'nın deniz suyu ve midyelerinin fekal koliform bakteriler tarafindan incelenmesi, Master's Thesis Istanbul University Institute of Graduate Studies In Sciences (in Turkish).

Kimiran, A., 1999, Examination of İstanbul seawater samples with regard to bacteria which are indicators of pollution, Doctoral Thesis, Istanbul University Institute of Graduate Studies In Sciences (in Turkish).

Munro, P.M., Gauthier, M.J., Breittmayer, V.A., Bongiovanni, J. (1989). Influence of some osmoregulaiton processes on starvation of Escherichia coli in seawater. Applied and Enviromental Microbiology, 55,2017-2014.

Neill, M. (2004). Microbiological indices for toplam coliform and $E$. coli bacteria in estuarine waters, Marine Pollution Bulletin. 49, 752-760.

Prescot, L. M., Harley, J. P., Klein, D. A. (1999). Microbiology, 4th ed., WCB Mc GrawHill Science, Boston, 0072951753, 978-0072951752.

Quinn, G., Keough, M. (2002). Experimental design and data analysis for biologists. Cambridge University Press, 537 pp.

Rhodes, M., Kator, H. (1988). Survival of Escherichia coli and Salmonella spp. in estuarine environments,
Applied and Environmental Microbiology, 54 (12), 2902-2907.

Shen, J., Jia, J.J. Mcallister Sisson, G. (2006). Inverse estimation of nonpoint sources of fecal coliform for establishing allowable load for Wye River, Maryland. Water Research,40, 3333 - 3342.

Shen, J., Jia, J.J., Mcallister Sisson, G. (2006). Inverse estimation of nonpoint sources of fecal coliform for establishing allowable load for Wye River, Maryland, Water Research, 40, 3333 - 3342.

Sivri, N., Seker, D.Z. (2010) Investigation of Enteric Bacteria of Surface Waters in the Southwestern Coast of Istanbul by means of GIS Turkish Journal of Fisheries and Aquatic Sciences. 10 (4), 505-511.

Sorensen, S.J. (1991). Survival of Escherichia coli K12 in seawater, FEMS Microbial Ecology, 85, 161-168.

Sur H. İ., Okuş E., Güven K.C., Yüksek A., Altık H., Kıratlı N., Ünlü S., Taş S., Aslan-Yılmaz A., Yılmaz N., Övez S., Müftüoğlu A. E., Karhan Ü., Öz İ. Demirel N. (2004), Water Quality Monitoring, Annual Report. Submitted to: İstanbul Water and Sewerage Administration (ISKI). Istanbul University, Institute of Marine Sciences and Management, İstanbul.

Touron, A., Berthe, T., Gargala, G., Fournier, M. Ratajczak, M., Servais, P. Petit, F. (2007). Assessment of faecal contamination and the relationship between pathogens and faecal bacterial indicators in an estuarine environment (Seine, France), Marine Pollution Bulletin, 54, 1441-1450

Unat, E.K., Ulusoy, M. Öztürk, M. (1986). İstanbul boğazı ve Haliç sularının 1986 Mayısındaki koliform bakteriler bakımından durumu, Türk Mikrobiyoloji Cemiyeti Dergisi, 16 (2-3), 45-49.

WPCR (2004) Water Pollution Control Regulation of the Turkish Republic Official Gazette, Turkish Federal Register December 31, 2004

Zeki, S. (2012). Assessing microbial water quality by membrane filtration and quantitative polymerase chain reaction $(q P C R)$ methods at Golden Horn (PhD thesis). Istanbul University, Istanbul, Turkey. 